\title{
CHALCONES TO CONTROL Alternaria alternata IN MURCOTT TANGOR FRUITS
}

\author{
CHALCONAS NO CONTROLE DE Alternaria alternata EM FRUTOS DE TANGOR \\ MURCOTE
}

\author{
Renato Barbosa CAMARgos ${ }^{1}$; Fabiano Jose PERINA ${ }^{2}$; Daniel Diego Costa CARVALHO ${ }^{3}$; \\ Eduardo ALVES ${ }^{1}$; Alessandra MASCARELLO ${ }^{4}$; \\ Louise Domeneghini CHIARADIA-DELATORRE ${ }^{4}$; Rosendo Augusto YUNES ${ }^{4}$; \\ Ricardo José NUNES ${ }^{4}$; Denilson Ferreira OLIVEIRA ${ }^{1}$ \\ 1. Universidade Federal de Lavras, Lavras, MG, Brazil, denilson@dqi.ufla.br; 2. Empresa Brasileira de Pesquisa Agropecuária, \\ Campina Grande, PB, Brazil; 3. Universidade Estadual de Goiás, Ipameri, GO, Brazil; 4. Universidade Federal de Santa Catarina, \\ Florianópolis, SC, Brazil.
}

\begin{abstract}
Alternaria brown spot (ABS), caused by the fungus Alternaria alternata pathotype tangerine, is one of the main phytosanitary problems for mandarin growers. About 15 applications per year of harmful fungicides are required for controlling $\mathrm{ABS}$ disease in citrus orchards. As chalcones seem to be less toxic to humans and environment than the commercial fungicides in use, this study initially aimed at synthesizing 137 chalcones through aldolic condensations between benzaldehydes and acetophenones. The resulting chalcones were screened for activity against $A$. alternata through a fungal growth assay that was carried out in 96-cell polypropylene plates, using the same concentration to all studied substances. The four active chalcones underwent conidia germination and mycelial growth, which confirmed the antifungal activity of the compounds. These chalcones were then poured onto Murcott tangor fruit that had been inoculated with conidia of the fungus. All four chalcones reduced the ABS progress to values significantly smaller $(\mathrm{P} \leq 0.05)$ than that observed for the control. Statistical calculations showed that the best results were afforded by two compounds, bearing a 2,4,5-trimethoxyphenyl group at position 3 of prop-2-enal and a 3-nitro- or 3-hydroxyphenyl group at position 1 of the aldehyde. Such compounds reduced the incidence of the disease in Murcott tangor fruit to values that did not differ statistically from those obtained with a commercial fungicide.
\end{abstract}

KEYWORDS: Alternaria brown spot. Citrus. Mandarin. Chemical control.

\section{INTRODUCTION}

Mandarin became more valued by global consumers of fresh fruits, mainly because it is easily peeled. Therefore, the production of mandarin increased within the citrus agribusiness (ZULIAN; DÖRR; ALMEIDA, 2013). Specifically in Brazil, about 959,672 tons of this fruit were produced in 51,841 hectares in 2012 (IBGE 2015). However, mandarin growers face a number of phytosanitary problems, among which we can highlight the Alternaria brown spot (ABS), which is caused by the fungus Alternaria alternata pathotype tangerine.This disease has been a serious threat for the production of mandarin in Brazil since 2006, when it was detected in Citrus reticulata var. Ponkan and hybrid tangor Murcott (Citrus reticulata $\mathrm{x}$ Citrus sinensis) (CARVALHO et al., 2008; STUART et al., 2009).

ABS affects shoots, young leaves and fruits, the symptoms being characterized by brownish black necrotic spots surrounded by a yellow halo (STUART et al., 2009). As the infected fruits are undervalued (VICENT et al. 2007), fungicides are usually employed to reduce the severity of this disease under field conditions (SOLEL; OREN; KIMCHI, 1997). In growing areas with high humidity and temperature, about 15 applications of fungicides are required per year to control this disease (TIMMER et al., 2003; BOSCH; BERG; PAVELEY, 2014), thus contaminating humans and the environment with substances of high toxicity (CARVALHO et al., 2007).

Chalcones appear as possible alternatives to circumvent such problem because some compounds of this class of substances have already presented activity against plant pathogenic fungi (SVETAZ et al., 2004; SIVAKUMAR; KUMAR; DOBLE, 2009). Furthermore, they apparently are more biodegradable and less toxic to humans and the environment than the commercial fungicides in use (COTORAS et al., 2011). Naturally occurring chalcones are key intermediates in flavonoid biosynthesis by plants, which can be easily synthesized through several procedures (MCMURRY 2000; SEBTI et al., 2001; EDDARIR et al., 2003; PETROV; IVANOVA; GEROVA, 2008). Therefore, the present work aimed at 
preparing 137 chalcones and evaluating their effects on A. alternata pathotype tangerine. To assist in the interpretation of results, principal components analysis (PCA) was used in order to summarize and identify correlations among the studied variables (GERALDINE et al., 2013; CARVALHO et al., 2014).

\section{MATERIAL AND METHODS}

\section{Synthesis of chalcones}

Chalcones (Figure 1) were prepared by aldolic condensations between benzaldehydes (1 $\mathrm{mmol})$ and acetophenones $(1 \mathrm{mmol})$ in methanol (20 $\mathrm{ml})$ containing potassium hydroxide $(0.5 \mathrm{~g} / \mathrm{mL})$ at room temperature, under magnetic stirring, for $24 \mathrm{~h}$ (MCMURRY, 2000).

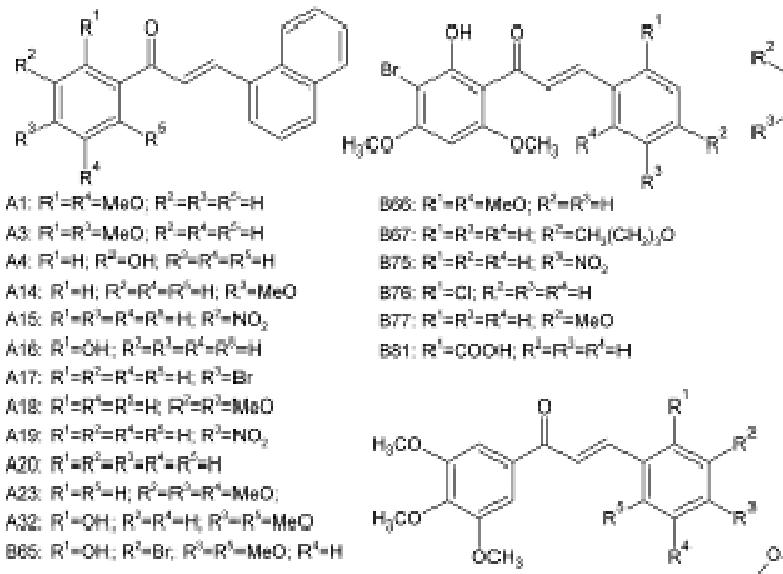

${ }_{\mathrm{CH}}$

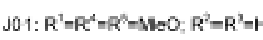

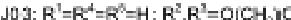
JDA: $\overrightarrow{\mathrm{R}}^{1}=\mathrm{F}^{4}=\mathrm{R}^{2}=\mathrm{H} ; \overrightarrow{\mathrm{R}}^{2} \overrightarrow{\mathrm{R}}^{2}=(\mathrm{CH})$.

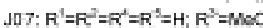

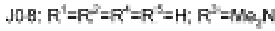

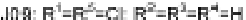

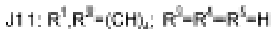
d. 3: $R^{i}=R^{3}=R^{2}=R^{3}-H ; R^{2}-M e$ J14: $R^{\prime}=R^{2}=R^{2}=R^{n}=R^{\prime}=H$

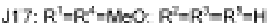

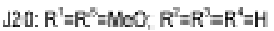
i2z: $\mathrm{R}^{\prime}=\mathrm{F}^{2}=\mathrm{R}^{2}=\mathrm{R}^{2}=\mathrm{H}_{;} \mathrm{R}^{2}=\mathrm{ND}$, MA: $\mathrm{R}^{1}=\mathrm{COOH} \mathrm{R}^{3}=\mathrm{R}^{3}=\mathrm{F}^{4}=\mathrm{R}^{3}=\mathrm{H}$ . $25 R^{i}=R^{H}-R^{i}-R^{3}-H \cdot R^{2}-M O O$<smiles>[R7]c1cc(C(=O)/C=C/c2ccc3nccnc3c2)c([R])c([Z7])c1[2H]</smiles>

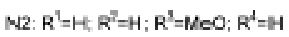

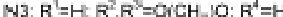

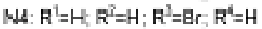
M5: $R^{2}=R^{2}=R^{3}=R^{2}=H$ 17. $R^{-1}-R^{3}-H R^{3}-N D R-H$ A N10 $R^{2}=H R^{2}=R^{3}=\mathrm{MeO} \quad R^{4}=H$ N12. $R^{12}=R^{3}=H=0, R^{8}=R^{4}=H$ Pod $\mathrm{R}^{2}=\mathrm{R}^{4}=\mathrm{A}=\mathrm{R} ; \mathrm{R}^{2}=\mathrm{R}^{2}=$ Po. $R^{\prime}=O H-R^{2}=R^{2}=R^{2}=H$ PVT: $R^{\prime}=R^{2}=H ; R^{2}=M o D \quad R^{3}=0$ Pae $R^{\prime}=R^{2}=R^{4}=H ; R^{2}=M$ For $R^{\prime}=R^{4}=H_{0} R^{3}=R^{3}=M \omega O$

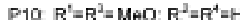

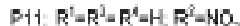
P12 $\mathrm{R}^{2}=\mathrm{H}^{2} \mathrm{R}^{2}=\mathrm{F}^{2}-\mathrm{R}^{2}-\mathrm{NeO}$

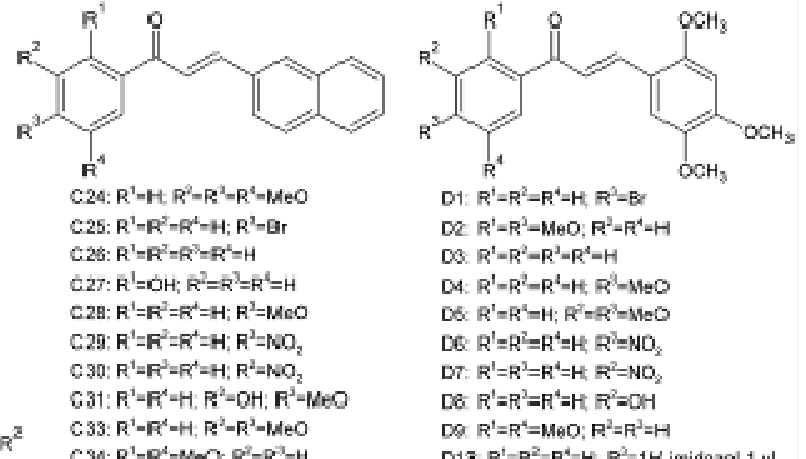

D1S $\mathrm{R}^{\prime}=\mathrm{R}^{2}=\mathrm{R}^{4}=\mathrm{H}, \mathrm{R}^{2}=1 \mathrm{H}$-imidexor-1-yI<smiles>[R]c1c([R])c([R])c(/C=C/C(=O)c2ccc3ccccc3c2)c([R])c1[R]</smiles>

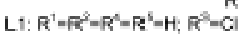
L2: $R^{3}-F^{2}-R^{0}-P^{3}-H ; R^{-}=G$

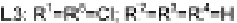
L4: $R^{\prime}=R^{\prime}=R^{2}=C, R^{2}=R^{\prime \prime}=H$ LE: $\mathrm{R}^{\prime}=\mathrm{R}^{\prime \prime}=\mathrm{R}^{\prime}=\mathrm{R}^{3}=\mathrm{H}_{;} \mathrm{R}^{2}=\mathrm{NO}$ LE: $R^{\prime}=R^{2}=R^{\prime}=R^{2}=H ; R^{2}=N D$

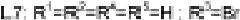
La $R^{i}-R^{3}-R^{i}-R^{3}-H, R^{3}-M+O$

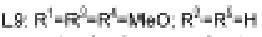
L10. $R^{\prime}=R^{\prime}-R^{\prime}=N 4 O, R^{\prime}=R^{2}=H$ L11: $R^{3}=R^{2}-H ; R^{i}=R^{3}-R^{4}-M a C$ L12: $\mathrm{R}^{\prime}=\mathrm{R}^{4}=\mathrm{R}^{\prime}=\mathrm{H}_{i} \mathrm{R}^{2}, \mathrm{R}^{3}=\mathrm{OCOCH}_{2} \mathrm{O}$ L13: $R^{\prime}=R^{\prime \prime}=R^{\prime \prime}=R^{1}-H, R^{x}=M e$ L14: $R^{i}=R^{2}=R^{\prime}=R^{3}=H, R^{3}=M s h$ 195. $R^{i}=R^{i}=R^{2}=H^{\prime} R^{2}, R^{3}=(\mathrm{CH})$, LF: $R^{i}, R^{2}=(C H) ; R^{2}-F^{2}-R^{2}=H$

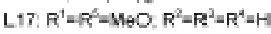
L18: $\mathrm{R}^{i}=\mathrm{R}^{2}=\mathrm{F}^{6}-\mathrm{R}^{3}=\mathrm{H}_{1} \mathrm{R}^{2}-\mathrm{O}_{2} \mathrm{CH}_{2} \mathrm{CH}_{3}$ L19. $R^{2}=R^{2}=R^{4}-R^{3}-H: R^{3}-F$ L20. $R^{\prime}=F ; R^{2}=R^{2}=R^{2}-R^{2}-H$ L21: $R^{\prime}=R^{2}=R^{2}=\bar{R}^{2}=\mathrm{R}^{\prime}=\mathrm{H}$ L22: $\vec{R}^{\prime}=\mathrm{ND}_{3} ; \overline{\mathrm{R}}^{\mathrm{I}}=\mathrm{R}^{3}=\mathrm{R}^{\mathrm{l}}=\mathrm{R}^{\mathrm{l}}=\mathrm{H}$

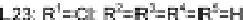
135 $R^{2}=R^{2}-R^{\prime}-R^{2}-H ; R^{2}-M O O$ 12 $2 \mathrm{~F}: \mathrm{R}^{\mathrm{i}}=\mathrm{F}^{2}=\mathrm{R}^{\mathrm{x}}=\mathrm{H}: \mathrm{R}^{2}=\mathrm{MO}, \mathrm{R}^{2}=\mathrm{OH}$ L23: $R^{-1}=R^{2}-R^{3}=H, R^{3}=N O O, R^{2}=600$ L28. $R^{3}=R^{2}=S 140 . R^{3}=F^{3}-R^{3}=H$

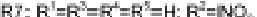

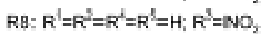
R19: $R^{4}=R^{3}=C t R^{2}=R^{4}=R^{2}=H$

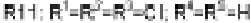

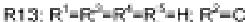
R15: $R^{1}-\Gamma^{2}-R^{i}-R^{\prime \prime}=R^{i}=H$ R16: $R^{1}=R^{2}=R^{2}=R^{3}=H ; R^{6}=M$

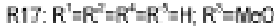

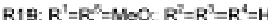
Ran: $R^{\prime}=R^{3}=R^{\prime}=\operatorname{MaO} \quad R^{\prime}=R^{i}=H$ R21: $R^{1}=\mathrm{R}^{3}=\mathrm{R}^{i}=\mathrm{R}^{n}=\mathrm{H}_{i} \mathrm{R}^{3}=\mathrm{Mc}_{\mathrm{C}} \mathrm{N}$

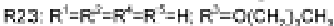

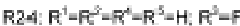
R26: $R^{i}=\Gamma^{3}=R^{2}=R^{3}=H, R^{3}=6$ $R 23: R^{4}=F^{2}=R^{2}=H ; R^{2} R^{3}=01 C_{3} O$ R29: $\mathrm{R}^{\prime}=\mathrm{P}^{2}=\mathrm{R}^{\prime}=\mathrm{H} ; \mathrm{R}^{2}, \mathrm{R}^{3}=\mathrm{CH}_{3}$

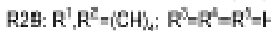
R3z: $\vec{R}^{1}=\mathrm{F}^{3}=\mathrm{R}^{2}=\mathrm{R}^{2}=\mathrm{H}_{;} \mathrm{R}^{2}=\mathrm{OOOH}$ $R 42 R^{\prime}=R^{*}=M 00, R^{3}=R^{3}=R^{3}=H$

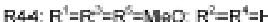

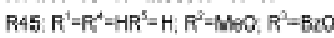

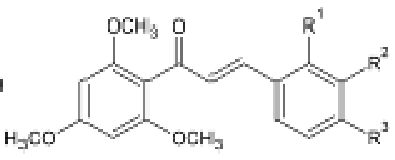

T35: $\pi^{1}=R-H: R^{2}=C$ T41. $R^{1}=R^{3}=H_{1} \cdot R^{2}=N_{1}$ T42: $\mathrm{A}: \mathrm{H} ; \mathrm{R}^{2}=\mathrm{R}^{2}=\mathrm{O}$

Figure 1. Chemical structures of the chalcones assayed in the present work.

The products were precipitated with water, followed by addition of $0.1 \mathrm{~g} / \mathrm{mL}$ hydrochloric acid. They were analyzed by thin layer chromatography (TLC) using aluminum plates pre-coated with silica gel (200 $\mu \mathrm{m}$ in thickness), using several solvent systems. Compounds were visualized under ultraviolet light (wavelength $=254$ and $360 \mathrm{~nm}$ ) or using sulfuric anisaldehyde solution followed by 
heat as the developing agent. Chalcones were recrystallized from hot ethanol to obtain pure substances at yields between $53 \%$ and $98 \%$. The structures of chalcones (Figure 1) were confirmed through comparisons of their melting points and nuclear magnetic resonance spectra with those previously published for chalcones from A, C and $\mathrm{P}$ series (CHIARADIA et al., 2008a), chalcones B (NAVARINI et al., 2009; BORCHHARDT et al., 2010), chalcones D (NUNES et al., 2013), chalcones J (COSTA et al., 2014), chalcones L and R (CHIARADIA et al., 2012), chalcones M (SALUM et al., 2013), chalcones N (MIELCKE et al., 2012) and chalcones T (CHIARADIA et al., 2008b).

\section{Production of conidia}

The fungus $A$. alternata pathotype tangerine used in this study was obtained as described by Carvalho et al. (2008). Briefly, fungal plugs $(90 \mathrm{~mm}$ $\varnothing)$ were transferred to PDA plates, which were maintained for seven days at $25^{\circ} \mathrm{C}$, under constant illumination provided by Philips daylight fluorescent lamps (20W, TLT, 75RS). Then, conidia were collected in $10 \mathrm{~mL}$ of an aqueous $0.01 \mathrm{~g} / \mathrm{mL}$ Tween $80^{\circledR}$ solution. The resulting mixture was filtered through sterilized cheesecloth to obtain the conidia suspension.

\section{Fungal growth assay (FGA)}

Aliquots $(250 \mu \mathrm{L})$ of solutions obtained by dissolving chalcones up to the concentration of 500 $\mu \mathrm{g} / \mathrm{mL}$ in aqueous $0.01 \mathrm{~g} / \mathrm{mL}$ Tween $80^{\circledR}$ solution, and $50 \mu \mathrm{L}$ of an aqueous suspension containing 2.6 x $10^{5}$ conidia of $A$. alternata per millilitre, were mixed to obtain a final suspension. From this suspension $20 \mu \mathrm{L}$ were withdrawn to be added to PDA $(130 \mu \mathrm{L})$ impregnated with oxytetracycline hydrochloride $500 \mathrm{mg}$ (Pfizer ${ }^{\circledR}, 0.55 \mathrm{mg} / \mathrm{mL}$ ) that was contained in cells of 96-cell polypropylene plates. Finally, the plates were wrapped with PVC film and incubated at $25^{\circ} \mathrm{C}$, under a $12 \mathrm{~h}$ photoperiod per day, for three days. According to Carvalho et al. (2011), the chalcones were considered to be active when preventing fungal growth under a visual observation.

\section{Conidia germination assay (CGA)}

To solutions $(1000 \mu \mathrm{L})$ of chalcones D7, D8, N5 and L21, at $500 \mu \mathrm{g} / \mathrm{mL}$ in aqueous 0.01 $\mathrm{g} / \mathrm{mL}$ Tween $80^{\circledR}$ solution, were added $200 \mu \mathrm{L}$ of an aqueous suspension at a concentration of $2.6 \times 10^{5}$ conidia of A. alternata per millilitre. Part $(520 \mu \mathrm{L})$ of each final suspension was spread on agar-water medium contained in a Petri dish, and incubated at $25^{\circ} \mathrm{C}$, under illumination, for $12 \mathrm{~h}$. Part (50) of the conidia were randomly evaluated, being considered germinated those conidia with germ tubes lengths greater than or equal to the diameter according to visual observation through a microscope.

\section{Mycelial growth assay (MGA)}

To PDA medium impregnated with tetracycline (Buncker) at $0.55 \mathrm{mg} / \mathrm{mL}$, contained in Petri dishes $(90 \mathrm{~mm} \varnothing)$ ), were added $500 \mu \mathrm{L}$ of chalcones D7, D8, N5 and L21 at $500 \mu \mathrm{g} / \mathrm{mL}$ in aqueous $0.01 \mathrm{~g} / \mathrm{mL}$ Tween $80^{\circledR}$ solution. Just after, a seven-day-old PDA agar plug, containing mycelium of $A$. alternata pathotype tangerine was transferred to the center of the Petri dish containing the PDA medium, which was incubated at $25^{\circ} \mathrm{C}$, under $12 \mathrm{~h}$ photoperiod, for seven days. The diameters of the colonies were then measured with a caliper rule (Pittsburg, USA).

The FGA, CGA and MGA experiments were carried out with four replicates, using the following solutions as controls: (1) Tween $80^{\circledR}$ at $0.01 \mathrm{~g} / \mathrm{mL}$ in water, (2) fungicide Dacobre ${ }^{\circledR}$ (tetrachloroisophthalonitrile $250 \mathrm{~g} / \mathrm{kg}$ and dicopper chloride trihydroxide $504 \mathrm{~g} / \mathrm{kg}$, Iharabras S.A. Indústria Química) at $3.5 \mathrm{~g} / \mathrm{L}$ in Tween $80^{\circledR}$ at 0.01 $\mathrm{g} / \mathrm{mL}$ and (3) Amistar $^{\circledR}$ (methyl (E)-2-\{2-[6-(2cyanophenoxy)pyrimidin-4-yloxy]phenyl $\}-3-$

methoxyacrylate $500 \mathrm{~g} / \mathrm{kg}$, Syngenta Proteção de Cultivos Ltda.) at $0.16 \mathrm{~g} / \mathrm{L}$ in Tween $80^{\circledR}$ at 0.01 $\mathrm{g} / \mathrm{mL}$.

\section{Murcott tangor fruits assay (MTFA)}

Only chalcones D7, D8, N5 and L21 were used in this experiment, which was carried out by adapting the method described by Carvalho et al. (2011). Fresh, ripe and healthy Murcott tangerine fruits were washed with sterile water and dried for 60 min under aseptic conditions in a laminar flux chamber. Four equidistant positions around the insertion point on fruits were marked using a permanent marker. Then, $20 \mu \mathrm{L}$ of an aqueous suspension resulting from the combination of 200 $\mu \mathrm{L}$ of a chalcone solution $\left(500 \mu \mathrm{g} / \mathrm{mL}\right.$ in Tween $80^{\circledR}$ at $0.01 \mathrm{~g} / \mathrm{mL}$ ) and $400 \mu \mathrm{L}$ of an aqueous suspension at a concentration of $1.3 \times 10^{6}$ conidia of $A$. alternata per millilitre, were poured on each selection point. All fruits were incubated in a humidity chamber at $25^{\circ} \mathrm{C}$, under $12 \mathrm{~h}$ photoperiod per day. At 8 and 12 days post inoculation (DPI), lesion diameter around each inoculation point was measured with a digital caliper rule (Pittsburg, USA). This experiment was carried out with four replications (fruits) per treatment, using the following controls: (1) Tween $80^{\circledR}$ at $0.01 \mathrm{~g} / \mathrm{mL}$ in 
water; (2) the fungicide Dacobre ${ }^{\circledR}$ at $3.5 \mathrm{~g} / \mathrm{L}$ in Tween $80^{\circledR}$ at $0.01 \mathrm{~g} / \mathrm{mL}$; and (3) the fungicide Amistar $^{\circledR}$ at $0.16 \mathrm{~g} / \mathrm{L}$ in Tween $80^{\circledR}$ at $0.01 \mathrm{~g} / \mathrm{mL}$. Values were converted into injured area $\left(\mathrm{mm}^{2}\right)$. For statistical analysis, the mean value of injured area per fruit was considered.

\section{Statistical analysis}

Data of all in vitro experiments were converted into percentage and subjected to analysis of variance (ANOVA) and means were compared by the Scott-Knott test $(\mathrm{P} \leq 0.05)$, using the software SISVAR 5.3 (FERREIRA, 2011). To assess the multivariate effect of the variables on values obtained in the assays (CGA, MGA and MTFA), the principal component analysis (PCA) was performed using the Rcmdr and FactoMineR packages from the ' $\mathrm{R}$ ' software 3.1.0 (R Development Core Team, Vienna, Austria).

\section{RESULTS}

\section{Fungal growth assay (FGA)}

Among all the 137 chalcones studied (Figure 1) only those denominated D7 [(2E)-1-(3- nitrophenyl)-3-(2,4,5-trimethoxyphenyl)prop-2-en1-one], D8 [(2E)-1-(3-hydroxyphenyl)-3-(2,4,5trimethoxyphenyl)prop-2-en-1-one], N5 [(2E)-1phenyl-3-(quinoxalin-6-yl)prop-2-en-1-one] and L21 [(2E)-1-(1,3-benzodioxol-5-yl)-3-phenylprop2-en-1-one], prevented the development of $A$. alternata in the FGA, which was used as an initial screening in the present work. Consequently, only these chalcones were selected to continue the study.

\section{Conidia germination (CGA) and mycelial growth (MGA) assays}

When submitted to the CGA, all the selected chalcones (D7, D8, N5 and L21) inhibited the germination of A. Alternate conidia (Table 1), though better performance was observed for the commercial fungicides in this assay. Among the four chalcones, D8 and N5 were the most active in this assay, inhibiting 85.5 and $87.5 \%$ of the conidia germination, respectively. In MGA, chalcone L21 was similar to the fungicide Amistar ${ }^{\circledR}$, inhibiting $36.2 \%$ of the mycelial growth of A. alternata (Table 1).

Table 1. Results of the conidia germination assay (CGA), mycelial growth assay (MGA) and Murcot tangor fruits assay (MTFA) at 8 and 12 days post-inocculation (DPI), which were carried out with the fungus Alternaria alternata pathotype tangerine ${ }^{1}$.

\begin{tabular}{|c|c|c|c|c|}
\hline \multirow[t]{2}{*}{ Treatments } & \multirow{2}{*}{$\begin{array}{c}\text { Inhibition in } \\
\text { CGA (\%) }\end{array}$} & \multirow{2}{*}{$\begin{array}{c}\text { Inhibition in } \\
\text { MGA }(\%)\end{array}$} & \multicolumn{2}{|c|}{ Injured area in MTFA $\left(\mathrm{mm}^{2}\right)$} \\
\hline & & & 8 DPI & 12 DPI \\
\hline $\mathrm{D}^{2}$ & $74.0 \mathrm{~d}$ & $19.7 \mathrm{c}$ & $39.2 \mathrm{aA}$ & $69.1 \mathrm{aB}$ \\
\hline $\mathrm{L} 21^{3}$ & $82.0 \mathrm{c}$ & $36.2 \mathrm{~b}$ & $51.8 \mathrm{bA}$ & $93.6 \mathrm{bB}$ \\
\hline$D 8^{4}$ & $85.5 \mathrm{~b}$ & $22.8 \mathrm{c}$ & $30.8 \mathrm{aA}$ & $53.2 \mathrm{aB}$ \\
\hline $\mathrm{N} 5^{5}$ & $87.5 \mathrm{~b}$ & $19.7 \mathrm{c}$ & $53.3 \mathrm{bA}$ & $104.4 \mathrm{bB}$ \\
\hline Dacobre $^{\circledR 6}$ & $91.5 \mathrm{a}$ & $43.6 \mathrm{a}$ & $31.4 \mathrm{aA}$ & $66.5 \mathrm{aB}$ \\
\hline Amistar ${ }^{\circledR 7}$ & $92.0 \mathrm{a}$ & $35.6 \mathrm{~b}$ & $51.9 \mathrm{bA}$ & $86.8 \mathrm{bB}$ \\
\hline Tween $80^{\circledR}$ & $0 \mathrm{e}$ & $0 \mathrm{~d}$ & $80.5 \mathrm{cA}$ & $172.6 \mathrm{cB}$ \\
\hline $\begin{array}{l}\text { Coefficient of } \\
\text { variation }(\%)\end{array}$ & 3.34 & 12.76 & 16.75 & 12.65 \\
\hline
\end{tabular}

${ }^{1}$ Means of four replicates with the same small letter in a column, or the same capital letter in a line, do not differ statistically (P $\left.\leq 0.05\right)$ according to the Scott-Knott method; ${ }^{2}(2 E)$-1-(3-nitrophenyl)-3-(2,4,5-trimethoxyphenyl)prop-2-en-1-one; ${ }^{3}[(2 E)$-1-(1,3-benzodioxol-5yl)-3-phenylprop-2-en-1-one; ${ }^{4}(2 E)$-1-(3-hydroxyphenyl)-3-(2,4,5-trimethoxyphenyl)prop-2-en-1-one; ${ }^{5}$ [(2E)-1-phenyl-3-(quinoxalin-6yl)prop-2-en-1-one; ${ }^{6}$ Tetrachloroisophthalonitrile $250 \mathrm{~g} / \mathrm{kg}$ and Dicopper chloridetrihydroxide $504 \mathrm{~g} / \mathrm{kg}$ (Iharabras S.A. Indústria Química) at $3.5 \mathrm{~g} / \mathrm{L}$ in Tween $80^{\circledR}$ at $0.01 \mathrm{~g} / \mathrm{mL}$; ${ }^{7}$ Methyl (E)-2-\{2-[6-(2-cyanophenoxy)pyrimidin-4-yloxy]phenyl $\}-3-$ methoxyacrylate $500 \mathrm{~g} / \mathrm{kg}$ (Syngenta Proteção de Cultivos Ltda) at $0.16 \mathrm{~g} / \mathrm{L}$ in Tween $80^{\circledR}$ at $0.01 \mathrm{~g} / \mathrm{mL}$.

\section{Murcott tangor fruits assay (MTFA)}

Once the selected chalcones (D7, D8, N5 and L21) could act against A. alternaria by both inhibiting its conidium germination and mycelial growth, these substances were submitted to the Murcott tangor fruit assay (MTFA), which was performed under conditions more similar to those observed in the field than the other assays carried out in this study. All four chalcones were able to reduce the ABS progress to values significantly smaller $(\mathrm{P} \leq 0.05)$ than that observed for the control (Tween $80^{\circledR}$ ). It worths to notice that an increase in the ABS lesions $\left(\mathrm{mm}^{2}\right)$ over time occurred for all treatments, evidencing a decrease in the fungitoxic effect over time by chalcones and the commercial fungicides used as controls (Table 1). 


\section{Principal component analysis (PCA)}

The principal component analysis (PCA) of all the results revealed that $96.4 \%$ of the variance could be explained by the first two components $(85.3 \%$ and $11.1 \%)$, as shown in Figure 2.
CAMARGOS, R. B. et al.

Eigenvalues of the first and second components were 3.41 and 0.44 , respectively. CGA was positively correlated with MGA. Similarly, lesions at 8 DPI were positively correlated with the lesions at 12 DPI in the MTFA.

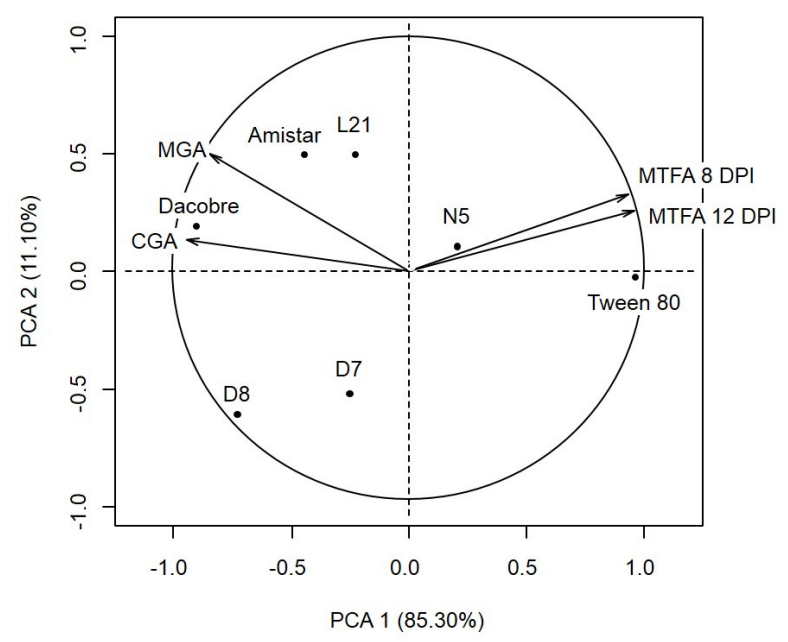

Figure 2. Principal component analysis (PCA) with traits. Results from the conidia germination assay (CGA), mycelial growth assay (MGA) and Murcot tangor fruits assay (MTFA) at 8 and 12 days postinoculation (DPI), were investigated for controlling of Alternaria alternata pathotype tangerine by chalcones, according to the two main components.

\section{DISCUSSION}

FGA was used to select chalcones from different series (A, B, C, J, L, M, N, P, R and T; Figure 1) with fungitoxic or even fugistatic effect on A. alternata. Among the 137 chalcones studied, only four were active against the fungus (D7, D8, N5 and L21), representing $2.9 \%$ of the samples. This percentage seems to be in accordance with other researches, in which a percentage around or lower than $10 \%$ of active substances has been verified in the screening for compounds with potential biological activity (LOUZADA et al., 2009; CARVALHO et al., 2011; CHIARADIA et al., 2012; MARTINS et al., 2013; FERREIRA et al., 2014). This occurs due to the variation in the chemical structures of the compounds.

Regarding chalcones from D series, the inactive components are mono- or di-substituted at positions 2 and/or 4 of the A-ring, while the active chalcones D7 and D8 contain substituents in position 3 of the A-ring, suggesting that this substitution pattern is important for achieving the desired activity against A. alternata. Using the 2,4,5-trimethoxyphenyl group as A-ring seems to be worthless, since compounds in the J series were all unable to prevent fungal growth. Similarly, a tri- or tetra-substituted A-ring (B, M and T series) confers no activity against $A$. alternata.

The activity of chalcones with rings condensed to the B-ring (A, C, L, N, P and R series) can also be compared with each other. Among the quinoxaline derivatives, only compound N5 (without substituent at A-ring) was active. Apparently, chemical groups with electron withdrawing or donor characteristic in any position of the A-ring cause loss of the activity to compounds in the $\mathrm{N}$ series. When the B-ring of N5 was replaced by a 2-naphthyl group the resulting compound (C26) showed no activity. Other chalcones with naphthyl groups as A or B-ring (A, $\mathrm{C}$ and $\mathrm{R}$ series) also did not prevent the development of the fungus. Thus, the naphthyl group seems to be useless to achieve antifungal activity. Among chalcones containing the 3,4methylenedioxy motif connected to the A-ring, only L21 (without substituent at B-ring) was active, indicating that electron withdrawing or donor groups in any position of B-ring cause loss of the activity to chalcones in L series. Surprisingly, when $\mathrm{A}$ and B-ring are interchanged in L21, generating $\mathrm{P} 1$, the activity is lost, evidencing that substitution of prop-2-enal to generate chalcones plays an important role in the activity of compounds against A. alternata.

Results obtained in CGA seem to be better 
than those observed by Cotoras et al. (2011) and Gaucher et al. (2013), who reported only 30\% and $50 \%$ inhibition of conidia germination of Botrytis cinerea and Venturia inaequalis, respectively. Apparently, this behaviour is mainly caused by the ketone group in the structures of chalcones (LÓPEZ et al., 2001), which can bind thiol groups in proteins, inhibiting fungal cell wall biosynthesis (BOWDEN; POZZO; DUAH, 1990).

MGA seems to be a less sensitive assay than CGA to screen chalcones for activity against $A$. alternata, since conidia exposed to the samples may suffer shrinkage (CARVALHO et al., 2011), which can cause irreversible ultra structural changes (PÂRVU et al., 2008). Consequently, chalcones D7, D8, N5 and L21 were able to delay A. alternata germination, but in MGA satisfactory results were only obtained for chalcone L21, which prevented mycelial growth in a manner similar to that observed for the commercial fungicide Amistar ${ }^{\circledR}$.

The commercial fungicides Dacobre ${ }^{\circledR}$ and Amistar $^{\circledR}$ belong to the cupric and strobilurine chemical groups, respectively, which can be used to control ABS in citrus (FEICHETENBERGER et al., 2005). Among these fungicides, Dacobre ${ }^{\circledR}$ was the most efficient against $A$. alternata, affording results in MTFA that were similar to those obtained with chalcones D7 and D8. According to Agrios (2005), the copper ion $\left(\mathrm{Cu}^{2+}\right)$ in Dacobre ${ }^{\circledR}$ is toxic to fungal cells because it reacts with sulfhydryl (-SH) groups of cystein residues of proteins, causing their denaturation. As D7 and D8 were more active against the fungus in the CGA than in the MGA, apparently the ketone group of chalcones also binds to $-\mathrm{SH}$ groups, causing the same effect (LÓPEZ et al., 2001; BOWDEN; POZZO; DUAH, 1990).

According to PCA, chalcones D7 and D8 were positioned close to each other (Figure 2), suggesting that both substances act in the same maner against $A$. alternata. Furthermore, PCA suggests that D7 and D8, positioned separately in an isolated quadrant and outlying from the lesions arrows, are better than N5 and L21. Indeed, PCA can separate effects that are not prone to separation in a mean test (CARVALHO et al., 2014). Consequently, ineffective treatments (eg. Tween $80^{\circledR}$ ) tend to be positioned near to the lesion arrows MTFA (Figure 2).

\section{CONCLUSIONS}

Among the 137 chalcones synthesized and submitted to assays with the fungus $A$. alternata, the best results were obtained with chalcones D7 and D8, which presented results similar to that obtained with the commercial fungicide Dacobre ${ }^{\circledR}$.

The results suggest that maximization of the antifungal acitivity by chalcones must be done by keeping B-ring as a 2,4,5-trimehoxyphenyl group and adding substituents only to position 3 of the Aring.

\section{ACKNOWLEDGEMENTS}

The authors thank Conselho Nacional de Desenvolvimento Científico e Tecnológico (CNPq), Fundação de Amparo à Pesquisa do Estado de Minas Gerais (FAPEMIG) and Coordenação de Aperfeiçoamento de Pessoal de Nível Superior (CAPES), for financial support and fellowships.

RESUMO: A mancha marron de Alternaria (MMA), causada pelo fungo Alternaria alternata patótipo tangerina, é um dos maiores problemas fitossanitários dos produtores de tangerina. Aproximadamente 15 aplicações de fungicidas de elevada periculosidade, por ano, são necessárias para o controle de MMA em várias plantações de citros. Como as chalconas parecem menos tóxicas para os seres humanos e para o ambiente que os fungicidas comerciais atualmente em uso, este estudo teve como objetivo inicial sintetizar 137 chalconas através da condensação aldólica de benzaldeídos com acetofenonas. As atividades das chalconas resultantes contra A. alternata foram avaliadas através do emprego de teste de crescimento fúngico em placas de polipropileno com 96 cavidades, empregando a mesma concentração para todas as substâncias estudadas. As quatro chalconas mais ativas foram submetidas a testes de germinação de conídios e de crescimento micelial, que confirmaram as atividades antifúngicas dos compostos selecionados. Estes foram então, aplicados em frutos de tangor Murcote que tinham sido inoculados com conídios do fungo. Todas as quatro chalconas reduziram o progresso de MMA a valores significativamente inferiores $(\mathrm{P} \leq 0.05)$ ao observado para o controle. Cálculos estatísticos mostraram que os melhores resultados foram obtidos para dois compostos, que tinham um grupo 2,4,5-trimetoxifenil na posição 3 do prop-2-enal e um grupo 3-nitro- ou 3-hidroxifenil na posição 1 do aldeído. Tais compostos reduziram a incidência da doença em frutos de tangor Murcote a valores que não diferiam estatisticamente do obtido com um fungicida comercial.

PALAVRAS-CHAVE: Mancha marrom de Alternaria. Citrus. Tangerina. Controle químico. 


\section{REFERENCES}

AGRIOS, G. N. Control of plant diseases. In: AGRIOS, G.N. Plant pathology. 5. ed. San Diego: Academic Press, 2005, p. 293-353. http://dx.doi.org/10.1016/B978-0-08-047378-9.50010-5

BORCHHARDT, D. M.; MASCARELlO, A.; CHIARADIA, L. D.; NUNES, R. J.; OLIVA, G.; YUNES, R. A.; ANDRICOPULO, A. D. Biochemical evaluation of a series of synthetic chalcone and hydrazide derivatives as novel inhibitors of cruzain from Trypanosoma cruzi. Journal of the Brazilian Chemical Society, São Paulo, v. 21, n. 1, p. 142-150, 2010. http://dx.doi.org/10.1590/S0103-50532010000100021

BOSCH, F. V. D. R. O.; BERG, F. V. D.; PAVELEY, N. Governing principles can guide fungicide-resistance management tactics. Annual Review of Phytopathology, Palo Alto, v. 52, n. 3, p. 9-21, 2014. http://dx.doi.org/10.1146/annurev-phyto-102313-050158

BOWDEN, K.; POZZO, A. D.; DUAH, C. K. Antibacterial activity of a series of substituted (E)-3-(4phenylbenzoyl) acrylic acids -chalcones, -2-hydroxychalcones and - $\alpha$-bromochalcones addition of cysteine to substituted 3-benzoylacrylic acids and related compounds. Journal of Chemical Research, St. Albans, v. 12, n. 1, p. 2801-2830, 1990.

CARVAlHO, D. D. C.; ALVES, E.; BATISTA, T. R. S.; CAMARGOS, R. B.; LOPES, E. A. G. L. Comparison of methodologies for conidia production by Alternaria alternata from citrus. Brazilian Journal of Microbiology, São Paulo, v. 39, n. 4, p. 792-798, 2008. http://dx.doi.org/10.1590/S1517-83822008000400036

CARVALHO, D. D. C.; ALVES, E.; CAMARGOS, R. B.; OLIVEIRA, D. F.; SCOLFORO J. R. S.; CARVALHO, D. A. Plant extracts to control Alternaria alternata in murcott tangor fruits. Revista Iberoamericana de Micologia, Bilbao, v. 28, n. 4, p. 173-178, 2011. http://dx.doi.org/10.1016/j.riam.2011.05.001

CARVALHO, D. D. C.; LOBO JUNIOR, M.; MARTINS, I.; INGLIS, P. W.; MELLO, S. C. M. Biological control of Fusarium oxysporum f. sp. phaseoli by Trichoderma harzianum and its use for common bean seed treatment. Tropical Plant Pathology, Brasília, v. 39, n. 5, p. 384-391, 2014. http://dx.doi.org/10.1590/S198256762014000500005

CARVALHO, D. D. C.; OLIVEIRA, D. F.; CORRÊA, R. S. B.; CAMPOS, V. P.; GUIMARÃES, R. M.; COIMBRA, J. L. Rhizobacteria able to produce phytotoxic metabolites. Brazilian Journal of Microbiology, São Paulo, v. 38, n. 4, p. 759-765, 2007. http://dx.doi.org/10.1590/S1517-83822007000400032

CHIARADIA, L. D.; MASCARELLO, A.; PURIFICAÇÃO, M.; VERNAL, J.; CORDEIRO, M. N. S.; ZENTENO, M. E.; VILARINO, A.; NUNES, R. J.; YUNES, R. A.; TERENZI, H. Synthetic chalcones as efficient inhibitors of Mycobacterium tuberculosis protein tyrosine phosphatase PtpA. Bioorganic and Medical Chemistry Letters, London, v. 18, n. 23, p. 6227-30, 2008 a.

http://dx.doi.org/10.1016/j.bmcl.2008.09.105

CHIARADIA, L. D.; DOS SANTOS, R.; VITOR, C. E.; VIEIRA, A. A.; LEAL, P. C.; NUNES, R. J.; CALIXTO, J. B.; YUNES, R. A. Synthesis and pharmacological activity of chalcones derived from 2,4,6trimethoxyacetophenone in RAW 264.7 cells stimulated by LPS: Quantitative structure-activity relationships. Bioorganic and Medical Chemistry Letters, London, v. 16, n. 2, p. 658-667, 2008b. http://dx.doi.org/10.1016/j.bmc.2007.10.039

CHIARADIA, L. D.; MARTINS, P. G. A.; CORDEIRO, M. N. S.; GUIDO, R. V. C.; ECCO, G.; ANDRICOPULO, A. D.; YUNES, R. A.; VERNAL, J.; NUNES, R. J.; TERENZI, H. Synthesis, biological evaluation, and molecular modeling of chalcone derivatives as potent inhibitors of Mycobacterium tuberculosis protein tyrosine phosphatases (PtpA and PtpB). Journal of Medical Chemistry, Washington, v. 55, n. 1, p. 390-402, 2012. http://dx.doi.org/10.1021/jm2012062 
COSTA, A.; CHIARADIA-DELATORRE, L. D.; BUBNIAK, L. S.; MASCARELLO, A.; MARZAROTTO, M. A. L.; MORAES, A. C. R.; STUMPF, T.R.; CORDEIRO, M. N. S.; YUNES, R. A.; NUNES, R. J.; SANTOS-SILVA, M. C. Apoptotic effect of synthetic 2',4',5'-trimethoxychalcones in human K562 and Jurkat leukemia cells. Medical Chemistry Research, New York, v. 23, n. 10, p. 4301-4319, 2014.

http://dx.doi.org/10.1007/s00044-014-1002-4

COTORAS, M.; MENDOZA, L.; YÁÑEZ, A. M. K.; CASTRO, P.; AGUIRRE, M. Fungitoxicity against Botrytis cinerea of a flavonoid isolated from Pseudognaphalium robustum. Molecules, Basel, v.16, n. 5, p. 3885-3895, 2011. http://dx.doi.org/10.3390/molecules16053885

EDDARIR, S.; COTELLE, N.; BAKKOUR, Y.; ROLANDO, C. An efficient synthesis of chalcones based on the Suzuki reaction. Tetrahedron Letters, Oxford, v. 44, n. 28, p. 5359-5363, 2003.

http://dx.doi.org/10.1016/S0040-4039(03)01140-7

FEICHETENBERGER, E.; SPÓSITO, M. B.; PIO, R. M.; CASTRO, J. L. Seleção de híbridos de tangerinas e híbridos de citros para tolerância à mancha marrom de Alternaria (Alternaria alternata Keissler). Citricultura Atual, Cordeirópolis, v. 8, n. 45, p. 8-10, 2005.

FERREIRA, D. F. Sisvar: a computer statistical analysis system. Ciência e Agrotecnologia, Lavras, v. 35, n. 6, p. 1039-1042, 2011.

FERREIRA, N. C.; MARQUES, I. A.; CONCEIÇÃO, W. A.; MACEDO, B. MACHADO, C. S.; MASCARELLO, A.; CHIARADIA, L. D.; YUNES, R. A.; NUNES, R. J.; HUGHSON, A. G.; RAYMOND, L. D.; PASCUTTI, P. G.; CAUGHEY, B.; CORDEIRO, Y. Anti-Prion Activity of a Panel of Aromatic Chemical Compounds: In Vitro and In Silico Approaches. Plos One, San Francisco, v. 9, n. 1, p. 1-9, 2014.

GAUCHER, M.; BERNONVILLE, T. D.; LOHOU, D.; GUYOT, S.; GUILLEMETTE, T.; BRISSET, M. N.; DAT, J. F. Histolocalization and physico-chemical characterization of dihydrochalcones: Insight into the role of apple major flavonoids. Phytochemistry, New York, v. 90, p. 78-89, 2013.

http://dx.doi.org/10.1016/j.phytochem.2013.02.009

GERALDINE, A. M.; LOPES, F. A. C.; CARVALHO, D. D. C.; BARBOSA, E. T.; RODRIGUES, A. R.; BRANDÃO, R. S.; ULHOA, C. J.; JUNIOR, L. J. Cell wall-degrading enzymes and parasitism of sclerotia are key factors on field biocontrol of white mold by Trichoderma spp. Biological Control, Coimbatore, v. 67, n. 3, p. 308-316, 2013. http://dx.doi.org/10.1016/j.biocontrol.2013.09.013

INSTITUTO BRASILEIRO DE GEOGRAFIA E ESTATÍSTICA (IBGE). Produção Brasileira de Tangerina, Brasilia, 2015. Disponível em: https://www.embrapa.br/documents/1355135/1906114/b1_tangerina.pdf/3276ad25-084d-48ce-aeb3050ffe7dc261. Acesso em: 7 Abr. 2015.

LÓPEZ, S. N.; CASTELLI, M. V.; ZACCHINO, S. A.; DOMÍNGUEZ, J. N.; LOBO, G.; CHARRISCHARRIS, J.; CORTÉS, J. C.; RIBAS, J. C.; DEVIA, C.; RODRIGUEZ, A. M.; ENRIZ, R. D. In vitro antifungal evaluation and structure-activity relationships of a new series of chalcones derivatives and synthetic analogues, with inhibitory properties against polymers of the fungal cell wall. Bioorganic and Medical Chemistry Letters, London. v. 9, n. 8, p. 1999-2013, 2001. http://dx.doi.org/10.1016/S0968-0896(01)00116-X

LOUZADA, G. A. S.; CARVALHO, D. D. C.; MELLO, S. C. M.; LOBO JÚNIOR, M.; MARTINS, I.; BRAÚNA, L. M. Potencial antagônico de Trichoderma spp. originários de diferentes agroecossistemas contra Sclerotinia sclerotiorum e Fusarium solani. Biota Neotropica, Campinas, v. 9, n. 3, p. 145-149, 2009. http://dx.doi.org/10.1590/S1676-06032009000300014 
MARTINS P. G. A.; MENEGATTI, A. C. O.; CHIARADIA-DELATORRE, L. D.; OLIVEIRA, K. N.; GUIDO, R. V. C.; ANDRICOPULO, A. D.; VERNAL, J.; YUNES, R. A.; TERENZI, H. Synthetic chalcones and sulfonamides as new classes of Yersinia enterocolitica YopH tyrosine phosphatase inhibitors, European Journal of Medicinal Chemistry, Paris, v. 64, p. 35-41, 2013. http://dx.doi.org/10.1016/j.ejmech.2013.04.018

MCMURRY, J. Carbonyl condensation reactions. In: Organic Chemistry. 5. ed. Pacific Grove: Brooks/Cole, 2000, p. 345-359.

MIELCKE, T. M.; MASCARELLO, A.; FILIPPI-CHIELA, E.; ZANIN, R. F.; LENZ, G.; LEAL, P. C.; CHIARADIA, L. D.; YUNES, R. A.; NUNES, R. J.; BATTASTINI, A. M.; MORRONE, F. B.; CAMPOS, M. M.. Activity of novel quinoxaline-derived chalcones on in vitro glioma cell proliferation. European Journal of Medicinal Chemistry, Paris, v. 48, p. 255-264, 2012. http://dx.doi.org/10.1016/j.ejmech.2011.12.023

NAVARINI, A. L.; CHIARADIA, L. D.; MASCARELLO, A.; FRITZEN, M.; NUNES, R.J.; YUNES, R. A.; CRECZYNSKI-PASA, T. B. Hydroxychalcones induce apoptosis in B16-F10 melanoma cells via GSH and ATP depletion. European Journal of Medicinal Chemistry, Paris. v. 44, p. 1630-1637, 2009. http://dx.doi.org/10.1016/j.ejmech.2008.09.009

NUNES, A. S.; CAMPOS, V. P.; MASCARELLO, A.; STUMPF, T. R.; CHIARADIA-DELATORRE, L. D.; MACHADO, A. R. T.; SANTOS JÚNIOR, H. M.; YUNES, R. A.; NUNES, R. J.; OLIVEIRA, D. F. Activity of chalcones derived from 2,4,5-trimethoxybenzaldehyde against Meloidogyne exigua and in silico interaction of one chalcone with a putative caffeic acid 3-O-methyltransferase from Meloidogyne incognita. Experimetal Parasitology, New York, v. 135, n. 4, p. 661-668, 2013. http://dx.doi.org/10.1016/j.exppara.2013.10.003

PÂRVU, M.; PÂRVU, A. E.; CRACIUN, C.; BARBU-TUDORAN, L.; TAMAS, M. Antifungal activities of Chelidonium majus extract on Botrytis cinerea in vitro and ultrastructural changes in its conidia. Journal of Phytopatholy, Berlin, v. 156, n. 9, p. 550-552, 2008. http://dx.doi.org/10.1111/j.1439-0434.2008.01410.x

PETROV, O.; IVANOVA, Y.; GEROVA, M. $\mathrm{SOCl}_{2} / \mathrm{EtOH}$ : catalytic system for synthesis of chalcones. Catalysis Communications, New York, v. 9, n. 2, p. 315-316, 2008.

http://dx.doi.org/10.1016/j.catcom.2007.06.013

SALUM, L. B.; ALTEI, W. F.; CHIARADIA, L. D.; CORDEIRO, M. N. S; CANEVAROLO, R. R.; MELO, C. P. S.; WINTER, E.; MATTEI, B.; DAGHESTANI, H. N.; SANTOS-SILVA, M. C.; CRECZYNSKI-PASA, T. B.; YUNES, J. A.; ANDRICOPULO, A. D.; DAY, B. W.; NUNES, R. J.; VOGT, A. Cytotoxic 3,4,5trimethoxychalcones as mitotic arresters and cell migration inhibitors. European Journal of Medicinal Chemistry, Paris, v. 63, p. 501-510, 2013. http://dx.doi.org/10.1016/j.ejmech.2013.02.037

SEBTI, S.; SOLHY, A.; TAHIR, R.; BOULAAJAJ, S.; MAYORAL, J. A.; FRAILE, J. M.; KOSSIR, A.; OUMIMOUN, H. Calcinated sodium nitrate/natural phosphate: an extremely active catalyst for the easy synthesis of chalcones inheterogeneous media. Tetrahedron Letters, Oxford, v. 42, n. 45, p. 7953-7955, 2001. http://dx.doi.org/10.1016/S0040-4039(01)01698-7

SIVAKUMAR, P. M.; KUMAR, T. M.; DOBLE, M. Antifungal activity, mechanism and qsar studies on chalcones. Chemical Biology and Drug Design, Oxford, v. 74, n. 1, p. 68-79, 2009.

http://dx.doi.org/10.1111/j.1747-0285.2009.00828.x

SOLEL, Z.; OREN, Y.; KIMCHI, M. Control of Alternaria brown spot of Minneola. Journal of Phytopatholy, Berlin, v. 145, p. 389-391, 1997. http://dx.doi.org/10.1111/j.1439-0434.1997.tb00420.x

STUART, R. M.; BASTIANEL, M.; AZEVEDO, F. A.; MACHADO, M. A. Alternaria brown spot. Laranja, Cordeirópolis. v. 30, n. 1-2, p. 29-44, 2009. 
SVETAZ, L.; TAPIA, A.; LÓPEZ, S. N.; FURLAN, R. L. E; PETENATTI, E.; PIOLI, R.; SCHMEDAHIRSCHMANN, G.; ZACCHINO, S. A. Antifungical chalcones and new caffeic acid esters from Zuccagnia punctata against soybean infecting fungi. Journal of Agricultural and Food Chemistry, Washington, v. 52, n. 11, p. 3297-3300, 2004. http://dx.doi.org/10.1021/jf035213x

TIMMER, L. W.; PEEVER, T. L.; SOLEL, Z.; AKIMITSU, K. Alternaria diseases of citrus - novel pathosystems. Phytopathologia Mediterranea, Firenze, v. 42, n. 2, p. 99-112, 2003.

VICENT, A.; BADAL, J.; ASENSI, M. J.; SANZ, N.; ARMENGOL, J.; GARCIA-JIMENEZ, J. Laboratory evaluation of citrus cultivars susceptibility and influence of fruit size on Fortune mandarin to infection by Alternaria alternata pv. citri. European Journal of Plant Pathology, Dordrecht, v. 110, n. 3, p. 245-251, 2007. http://dx.doi.org/10.1023/B:EJPP.0000019794.00000.02

ZULIAN, A.; DÖRR, A. C.; ALMEIDA, S. C. Citricultura e agronegócio cooperativo no Brasil. Revista Eletrônica em Gestão, Educação e Tecnologia Ambiental, Santa Maria, v. 11, n. 11, p. 2290-2306, 2013. 